\title{
ANALISIS KESALAHAN MAHASISWA PENDIDIKAN MATEMATIKA DALAM MENYELESAIKAN SOAL NILAI MUTLAK PADA MATERI BILANGAN REAL
}

\author{
Fanny Rahmasari ${ }^{1}$, Muntika Agus Lea ${ }^{2}$, Reni Aisawa ${ }^{3}$, Ramadhani ${ }^{4}$ \\ Universitas Muslim Nusantara Al Washliyah \\ Email : Fannyrrhsi212@gmail.com
}

\begin{abstract}
Abstrak
Tujuan pendidikan dalam pembelajaran dikatakan tercapai apabila mahasiswa mampu memahami, mendalami matematika dan mampu mengaplikasikannya dalam menyelesaikan masalah yang ada. Penelitian ini mempunyai tujuan untuk mendeskripsikan kesalahan mahasiswa dalam menyelesaikan soal nilai mutlak pada mata kuliah Analisis Real. Penelitian ini merupakan penelitian kualitatif, dengan menggunakan pendekatan penelitian yang dilakukan adalah mengamati kasus yang dilakukan mahasiswa dalam mengerjakan permasalahan dalam matematika yang berbentuk soal. Adapun subjek dalam penelitian ini adalah mahasiwa pendidikan matematika Fakultas Keguruan dan Ilmu Pendidikan Universitas Muslim Nusantara Al-Washliyah Medan semester VI kelas A Tahun akademik 2018/2019. Metode pengumpulan data yang digunakan pada penelitian ini adalah menggunakan metode tes dan wawancara. Penelitian ini dilaksanakan pada bulan April 2019. Sebelum peneliti melakukan analisis, peneliti memeriksa keabsahan data agar memperoleh data yang valid. Selanjutnya dari data yang sudah valid baru dianalisis yang kemudian ditarik suatu simpulan. Dari hasil penelitian didapatkan hasil bahwa, mahasiswa melakukan beberapa kesalahan yaitu : kesalahan dalam menemukan konsep nilai mutlak, Kesalahan konsep dalam penggunaan tanda pertidaksamaan, Kesalahan dalam langkah - langkah penyelesaian dan kesalahan tidak melanjutkan proses penyelesaian. Sehubungan dengan hal tesebut, penyebab kesalahan mahasiswa dalam menyelesaikan soal matematika dapat digolongkan menjadi tiga yaitu: mahasiswa itu sendiri, dosen dan fasilitas (buku acuan) yang digunakan.
\end{abstract}

Kata Kunci: Mahasiswa, Pendidikan Matematika, Bilangan Real

\begin{abstract}
The purpose of education in learning is said to be achieved if students are able to understand, explore mathematics and be able to apply it in solving existing problems. This study aims to describe student errors in solving the absolute value questions in the Real Analysis course. This research is a qualitative research, by using a research approach that is carried out is observing cases conducted by students in working on problems in mathematics in the form of questions. The subjects in this study were mathematics education students at the Faculty of Teacher Training and Education at
\end{abstract}


Muslim Nusantara Al-Washliyah Medan University in semester VI class A 2018/2019 academic year. Before the researcher conducts the analysis, the researcher checks the validity of the data in order to obtain valid data. Furthermore, from the data that has been valid recently analyzed, then a conclusion is drawn. The results showed that students made several mistakes, namely: errors in finding the concept of absolute value, conceptual errors in the use of inequality marks, errors in completion steps and errors not continuing the settlement process. In connection with this matter, the causes of student errors in completing mathematical questions can be classified into three, namely: the student himself, the lecturer and the facilities (reference books) used.

Keyword: Keywords: Students, Mathematics Education, Real Numbers

\section{PENDAHULUAN}

Tujuan pendidikan dalam pembelajaran dikatakan tercapai apabila mahasiswa mampu memahami, mendalami matematika dan mampu mengaplikasikannya dalam menyelesaikan masalah yang ada. Banyak hal yang mempengaruhi keberhasilan pembelajaran matematika di kampus antara lain: lingkungan kampus, mahasiswa, dosen, metode pembelajaran, dan sebagainya. Dilihat dari peserta didik faktor yang mempengaruhi keberhasilan pembelajaran matematika dapat karena faktor internal (dalam diri) dan eksternal (lingkungan). Permasalahan yang muncul adalah masih ditemukannya kesulitan dalam menyelesaikan soal yang berbentuk cerita dan cenderung menggunakan kata-kata (Karnasih, 2015). Kesalahan lain yang sering terjadi adalah karena mahasiswa menghafal rumus tetapi tidak memahami konsep secara utuh sehingga cenderung cara praktis yang digunakan (Amir, 2017).

Menurut Sukirman (1985 : 16), kesalahan adalah penyimpangan terhadap hal- hal yang benar yang sifatnya sistematis, konsisten maupun isidental pada daerah tertentu. Sehingga dapat disimpulkan bahwa kesalahan adalah sesuatu yang tidak sesuai dengan prosedur dengan aturan yang ada yang mempunyai sifat sistematis, konsisten dan isidental. Adapun penyebab dari kesalahan itu sendiri. Menurut Malau (1996:44) penyebab kesalahan yang sering dilakukan siswa dalam menyelesaikan soal-soal matematika dapat dilihat dari beberapa hal antara lain disebabkan kurangnya pemahaman atas materi prasyarat maupun materi pokok yang dipelajari, kurangnya penguasaan bahasa matematika, keliru menafsirkan atau menerapkan rumus, salah perhitungan, kurang teliti, lupa konsep. Dari uraian di atas, peneliti mencoba menganalisis dan mengungkapkan jenis-jenis kesalahan, kecenderungan kesalahan, dan penyebab terjadinya kesalahan keterampilan, kesalahan konsep dan kesalahan prinsip yang dilakukan mahasiswa pendidikan matematika. 
Dalam pembelajaran yang disampaikan peneliti lebih fokus pada materi Bilangan Real dalam Nilai Mutlak. Materi ini terdapat dalam mata kuliah Analisis Real yang ditempuh mahasiswa semester VI kelas A Fakultas Keguruan dan Ilmu Pendidikan (FKIP) Program Studi Pendidikan Matematika Universitas Muslim Nusantara (UMN) AlWashliyah Medan. Dari pengamatan peneliti mahasiswa cenderung memiliki kesalahan dalam pembelajaran mata kuliah Analisis Real khususnya materi Nilai Mutlak, sehingga peneliti bermaksud untuk menganalisis kesalahan mahasiswa khususnya pada materi Nilai Mutlak.

Berdasarkan Uraian penjelasan dan penelitian terdahulu, perlu adanya analisis tentang kesalahan mahasiswa dalam menyelesaikan soal dalam materi Nilai Mutlak pada mata kuliah Analisis Real agar dapat mengetahui dan mengidentifikasi yang selanjutnya mendeskripsikan secara lebih jelas kesalahan apa saja yang dilakukan mahasiswa. Disamping itu, pada penelitian ini juga akan digali mengapa mahasiswa melakukan kesalahan tersebut, agar para pengajar mengetahui penyebab mahasiswa melakukan kesalahan dan dapat memperbaiki melalui pembelajaran.

\section{METODE PENELITIAN}

Penelitian ini merupakan penelitian kualitatif, yang dilakukan dengan cara mengamati kasus yang dilakukan mahasiswa dalam mengerjakan permasalahan dalam matematika yang berbentuk soal. Salah satu cara untuk mengetahui kesalahan yang dilakukan oleh mahasiswa perlu diadakan analisis terhadap hasil pekerjaan mahasiswa sehingga diperoleh gambaran pada bagian mana saja mahasiswa melakukan kesalahankesalahan dalam menyelesaikan soalsoal pada pokok bahasan Nilai Mutlak. Penelitian ini mempunyai tujuan untuk mendeskripsikan kesalahan mahasiswa dalam menyelesaikan soal nilai mutlak pada mata kuliah Analisis Real. Adapun subjek dalam penelitian ini adalah mahasiwa pendidikan matematika semester VI kelas A FKIP UMN Al-Washliyah Medan Tahun akademik 2018/2019.

Instrumen dalam penelitian ini adalah peneliti sendiri, karena dalam penelitian ini peneliti sebagai penentu dalam mengumpulkan, menganalisis dan menyajikan data. Sedangkan instrumen bantu dalam penelitian ini adalah soal tes dan wawancara. Tes diberikan berbentuk uraian kepada mahasiswa semester VI kelas A pada materi Nilai Mutlak. Tes tertulis bentuk uraian ini didasarkan pada pertimbangan bahwa tes ini menuntut kemampuan mahasiswa untuk dapat mengorganisir, menginterpretasi, menghubungkan pengetahuanpengetahuan yang telah dimiliki untuk menjawab suatu permasalahan. Wawancara pada penelitian ini adalah dengan cara mewawancarai subjek berdasarkan hasil tertulisnya terhadap soal yang diberikan, bertujuan untuk mengklarifikasi jawaban tertulis subjek dan untuk memperoleh informasi penyebab mahasiswa melakukan kesalahan. Hasil dari wawancara mahasiswa dapat dibuktikan secara kongkrit. Sebelum 
peneliti melakukan analisis, peneliti memeriksa keabsahan data agar memperoleh data yang valid. Selanjutnya dari data yang sudah valid baru dianalisis yang kemudian ditarik suatu simpulan.

\section{HASIL DAN PEMBAHASAN}

Penelitian ini dilaksanakan pada mahasiswa semester VI tahun ajaran 2018-2019 di UMN Al-
Washliyah Medan. Jumlah satu kelas terdiri dari 37 mahasiswa. Mahasiswa diberikan soal uraian terkait materi nilai mutlak, setelah mahasiswa memperoleh materi tersebut. Mahasiswa tidak diperbolehkan membuka buku catatan selama mengerjakan soal tersebut. Berikut ini adalah soal yang diberikan kepada mahasiswa, yaitu :

1. Tentukan $\mathrm{x} \in \mathrm{R}$, yang memenuhi ketaksamaan $|4 x-3| \leq 13$

2. Tentukan dan gambar sketsa himpunan pasangan berurut $(a, b)$ di $R \times R$ yang memenuhi $|x|-|y|=2$.

\section{peneliti}

Setelah semua mahasiswa mengerjakan soal tersebut, selanjutnya

jawaban mahasiswa untuk mendapatkan subjek penelitian. Berdasarkan kriteria yang sudah ditetapkan oleh peneliti, terdapat beberapa mahasiswa yang memenuhi kriteria sebagai berikut : 1) jawaban mahasiswa mewakili kesalahan yang banyak dilakukan oleh mahasiswa, 2) jawabannya relatif relevan dengan soal tes, 3) mempunyai komunikasi yang baik. Berdasarkan kriteria tersebut, terdapat 3 mahasiswa yang memenuhi kriteria yang telah ditetapkan. Ketiga mahasiswa tersebut disimbolkan dengan subjek A, subjek B dan Subjek $\mathrm{C}$, dengan kategori rendah, sedang dan tinggi. Setelah memperoleh tiga subjek, selanjutnya peneliti mewawancarai subjek terkait jawaban tertulisnya.

Berdasarkan hasil tes yang telah dilakukan pada materi nilai mutlak diperoleh bahwa masih terdapat mahasiswa yang melakukan kesalahan dalam menyelesaikan soal terkait materi tersebut. Kesalahan yang menelaah

dilakukan mahasiswa terdiri dari kesalahan konsep, dan kesalahan prinsip. Materi nilai mutlak membutuhkan kemampuan memahami konsep dan prinsip. Pemahaman konsep yang maksud adalah salah satu kecakapan atau kemahiran matematika yang diharapkan dapat tercapai dalam belajar matematika. Prinsip yang dimaksud berkaitan dengan kemampuan menyusun algoritma dan melakukan operasi perhitungan sehingga menghasilkan jawaban yang benar dan tepat.

Berdasarkan pada hasil jawaban tertulis subjek dan dari hasil wawancara subjek, berkaitan dengan jawaban tertulisnya, berikut ini disajikan hasil analisis dari subjek penelitian:

1. Subjek A 


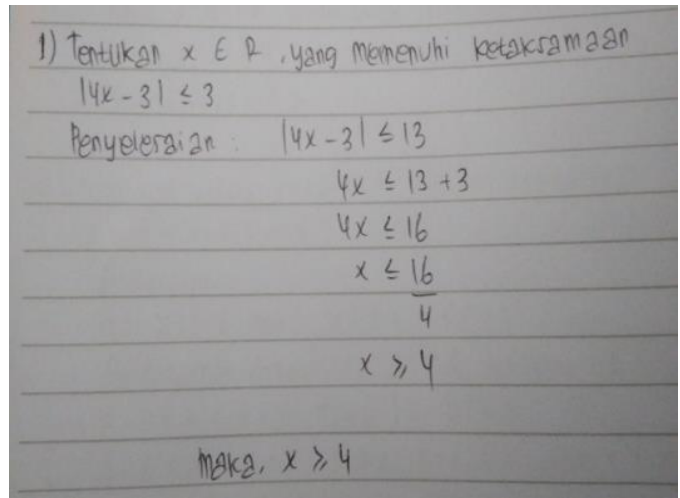

Gambar 1. Jawaban Nomor 1 oleh Subjek A

Berdasarkan hasil dari jawaban tertulis dan wawancara terkait hasil tertulis subjek A, didapatkan beberapa kesalahan yang dilakukan oleh subjek A, yaitu:

1. Kesalahan dalam menyelesaikan soal nilai mutlak, disini subjek A hanya berfokus pada satu kasus, sedangkan dalam menyelesaikan soal tersebut terdapat beberapa kasus yang akan dianalisis seperti kasus : 1) $|a| \leq b$, 2) $|-a| \leq b$, 3) $|-a| \leq-b$

2. Kesalahan dalam langkahlangkah penyelesaiannya, tidak memberikan penjelasan yang tepat.

3. Kesalahan konsep dalam penggunaan tanda pertidaksamaan $\leq$ dan $\geq$, seharusnya nilai $\mathrm{x}$ adalah $\mathrm{x} \leq$ 4, sedangkan pada jawaban subjek A adalah $\mathrm{x} \geq 4$. Sehingga penyelesaiannya menjadi kurang tepat.

Berikut ini adalah jawaban tertulis subjek A berdasarkan soal nomor 2:

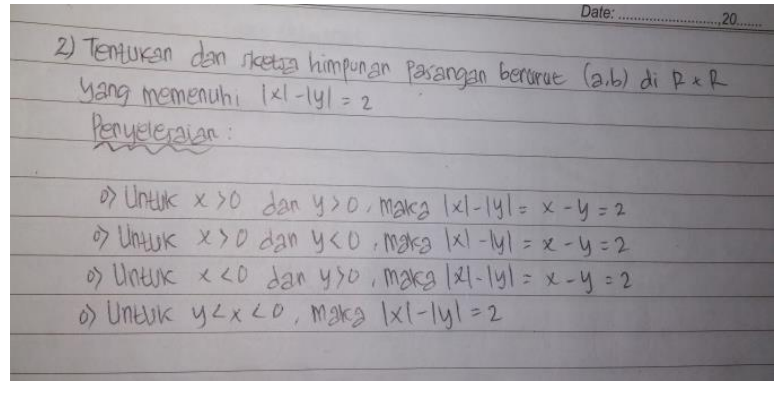

Gambar 2. Jawaban Soal Nomor 2 oleh subjek A

Berdasarkan hasil dari jawaban tertulis dan wawancara terkait hasil tertulis subjek A pada soal nomor 2, ditemukan kesalahan yang dilakukan subjek A, yaitu :

1. Kesalahan konsep dalam tanda pertidaksamaan. Terlihat dari jawaban subjek A, dimana pada $\mathrm{x}>0$ dan $\mathrm{y}<0$, maka seharusnya $\quad|x|-|y|=x-$ $(-y)=x+y=2$, karena $\mathrm{y}<$ 0 berarti y bernilai negatif. Untuk $\mathrm{x}<0$ dan $\mathrm{y}>0$ diperoleh $\quad|x|-|y|=-x-$ $y=2$, karena $x<0$ berarti $x$ bernilai negatif. Sedangkan jawaban tertulis subjek A adalah $|x|-|y|=x-y=2$. Untuk $\mathrm{y}<\mathrm{x}<0$, seharusnya $|x|-|y|=-x-(-y)=$ $-x+y=2$,sehingga jawaban subjek A menjadi kurang tepat. Ketika diwawancarai alasan subjek melakukan kesalahan ini adalah dikarenakan dia lupa dan kurang teliti.

2. Kesalahan prinsip, subjek A tidak mengikut sertakan sketsa/ gambar pada jawaban soal tersebut, sehingga jawaban tertulis subjek A tidak sempurna. Ketika 
diwawancarai subjek beralasan tidak memahami dalam pembuatan sketsa tersebut, dan tidak mengerti bagaimana cara menggambarkannya.

$$
\text { Berdasarkan dari hasil }
$$

analisis tersebut, dapat
A seperti yang tersaji dalam tabel di bawah ini :

disimpulkan kesalahan subjek

Tabel 1. Deskripsi Kesalahan Subjek A

\begin{tabular}{|l|l|}
\hline NO & \multicolumn{1}{|c|}{ Deskripsi Kesalahan } \\
\hline 1 & Kesalahan dalam menemukan konsep nilai mutlak \\
\hline 2 & Kesalahan konsep dalam penggunaan tanda pertidaksamaan \\
\hline 3 & Kesalahan dalam langkah - langkah penyelesaian \\
\hline 4 & Kesalahan tidak melanjutkan proses penyelesaian \\
\hline
\end{tabular}

2. Subjek B

Berikut ini adalah jawaban tertulis subjek B berdasarkan Nomor 1

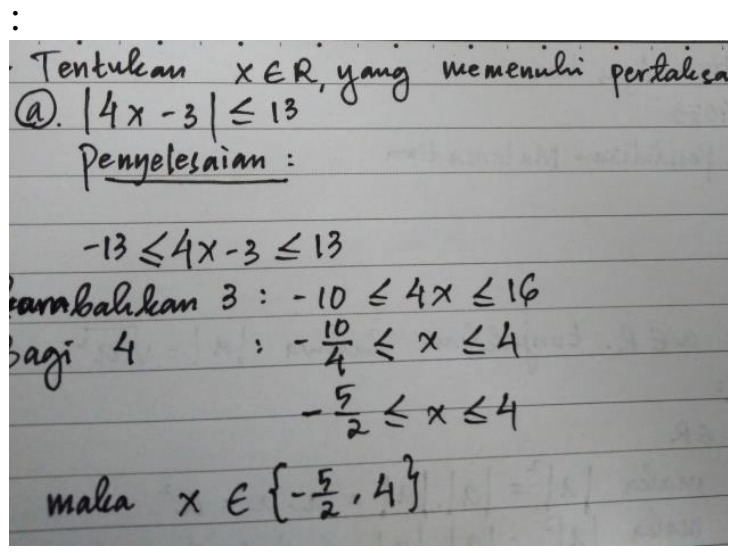

Gambar 3. Jawaban Soal Nomor 1

\section{Subjek B}

Berdasarkan hasil dari jawaban tertulis dan wawancara terkait hasil tertulis subjek B pada soal nomor 1, ditemukan beberapa kesalahan yang dilakukan subjek B, yaitu :

1. Kesalahan pada subjek B hampir sama dengan subjek A, hanya berfokus pada satu kasus, sedangkan dalam menyelesaikan soal tersebut terdapat beberapa kasus yang akan dianalisis seperti kasus : 1) $|\mathrm{a}| \leq \mathrm{b}, 2)|-\mathrm{a}| \leq \mathrm{b}, 3)|-\mathrm{a}| \leq-\mathrm{b}$ , namun jawaban subjek B sudah benar.

2. Kesalahan dalam mengerjakan soal tersebut, tidak sesuai dengan langkah-langkah penyelesaian. Ketika diwawancarai subjek yakin kalau jawabannya sudah tepat, dan dari wawancara tergali bahwa subjek mengalami kesalahan itu karena subjek masih kurang memahami konsep nilai mutlak.

3. Pada penyelesaian subjek tidak menjelaskan darimana $-13 \leq$ $4 x-3 \leq 13, \quad$ setelah diwawancarai subjek tidak tahu bagaimana menjelaskannya, dikarenakan subjek juga tidak memahami konsep materi nilai mutlak. 
Berikut ini adalah jawaban tertulis subjek B berdasarkan Nomor 2

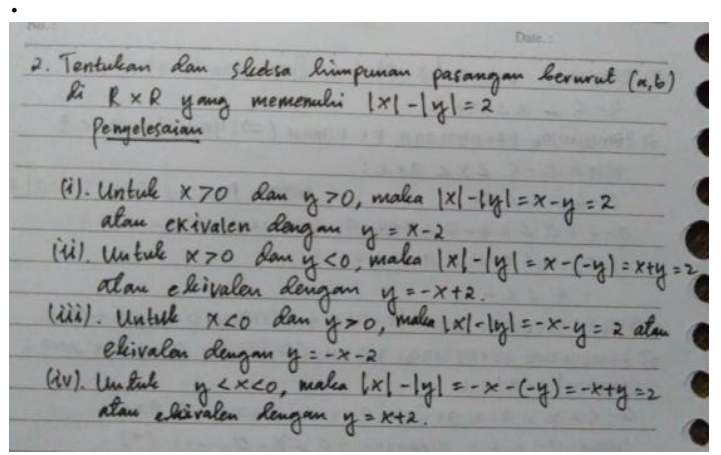

Gambar 4. Jawaban Soal Nomor 2 Subjek B

Berdasarkan hasil dari jawaban tertulis subjek B pada soal nomor 2, ditemukan beberapa kesalahan yang dilakukan subjek B, yaitu :

1. Kesalahan prinsip, subjek B tidak mengikut sertakan sketsa/ gambar pada jawaban soal tersebut, sehingga jawaban tertulis subjek tidak sempurna. Ketika diwawancarai subjek beralasan tidak memahami dalam pembuatan sketsa tersebut, dan tidak mengerti bagaimana cara menggambarkannya.

tertulis dan wawancara terkait hasil

Tabel 2. Deskripsi Kesalahan Subjek B

\begin{tabular}{|c|l|}
\hline No & \multicolumn{1}{c|}{ Deskripsi Kesalahan } \\
\hline 1 & Kesalahan dalam menemukan konsep nilai mutlak \\
\hline 2 & Kesalahan dalam langkah - langkah penyelesaian \\
\hline 3 & Kesalahan tidak melanjutkan proses penyelesaian \\
\hline
\end{tabular}

\section{Subjek C}

Berikut ini adalah jawaban tertulis subjek $\mathrm{C}$ berdasarkan Nomor 1

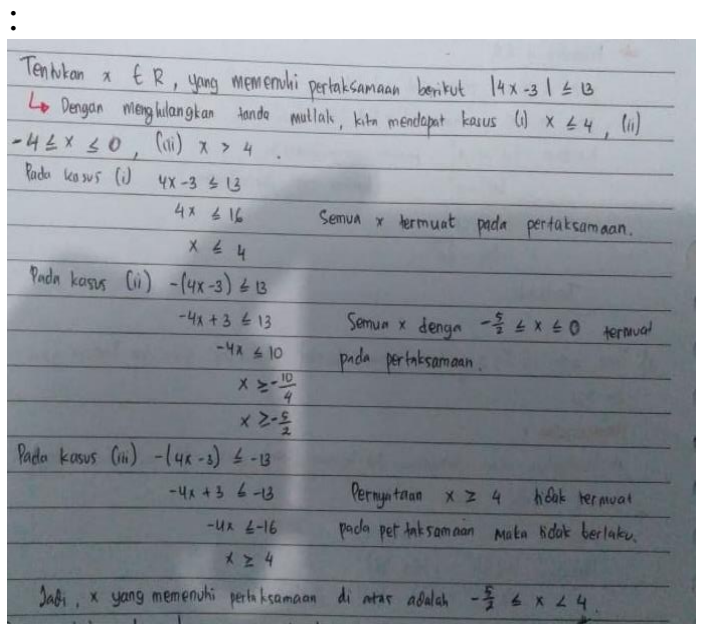

Gambar 5. Jawaban Soal Nomor 1 Subjek C

Berdasarkan hasil dari jawaban tertulis dan wawancara terkait hasil

tertulis subjek C, tidak ditemukan kesalahan yang dilakukan oleh subjek C. Jawaban tertulis subjek memenuhi persyaratan dalam menyelesaikan soal tersebut menggunakan tiga kasus : 1) $|\mathrm{a}| \leq \mathrm{b}, 2)|-\mathrm{a}| \leq \mathrm{b}, 3)|-\mathrm{a}| \leq-\mathrm{b}$. Pada saat diwawancarai subjek sangat paham apa yang dikerjakan, dan subjek dapat menjelaskan sesuai dengan apa yang telah ia kerjakan. Sehingga penyelesaiannya juga benar dan tepat.

Berikut ini adalah jawaban tertulis subjek $\mathrm{C}$ berdasarkan Nomor 2 


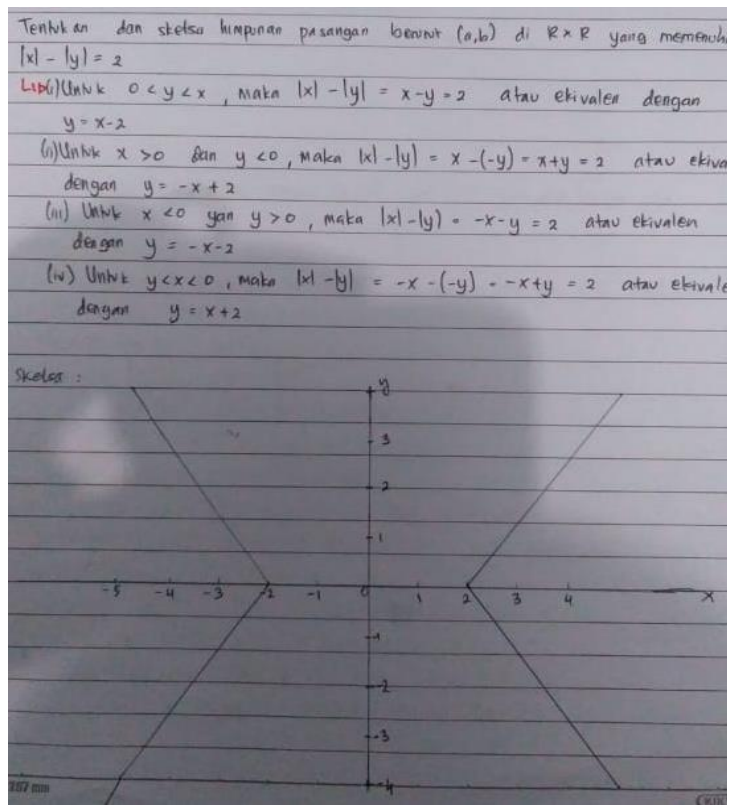

Gambar 6. Jawaban Soal

Nomor 2 Subjek C

Berdasarkan hasil dari jawaban tertulis dan wawancara terkait hasil tertulis subjek $\mathrm{C}$, tidak ditemukan kesalahan yang dilakukan oleh subjek C. Pada saat diwawancarai subjek paham dan mengerti konsep nilai mutlak. Jawaban tertulis subjek telah memenuhi persyaratan dengan membuat sketsa seperti yang diminta pada soal tersebut. Sehingga hasil penyelesaianya pun benar dan tepat.

Berdasarkan pada tabel 1dan tabel 2 di atas, subjek A melakukan 4 jenis kesalahan, subjek B melakukan 3 jenis kesalahan, sedangkan subjek $C$ tidak melalukan satupun kesalahan. Dari hasil wawancara dapat diketahui bahwa alasan kenapa subjek A dan subjek B melakukan kesalahan hampir sama. Mereka melakukan kesalahan dikarenakan subjek A dan subjek B kurang memahami materi pertidaksamaan dan kurang teliti dalam mengerjakan soal tersebut.
Akibat dari tidak memahami materi nilai mutlak akhirnya subjek melakukan beberapa kesalahan dalam mengerjakan soal dan tidak memahami soal yang diberikan.

Dapat disimpulkan bahwa penyebab terjadi kesalahan mahasiswa adalah : Mahasiswa tidak bisa menghafal rumus yang akan digunakan, kurang cermat, kurang teliti dalam menjawab, tidak ada persiapan menghadapi tes, tidak ingat cara penyelesaian soal bentuk tersebut, dan tidak cukup waktu dalam mengikuti tes.

\section{SIMPULAN DAN SARAN}

Berdasarkan hasil penelitian, dapat disimpulkan bahwa : Subjek A melakukan 4 kesalahan yaitu : Kesalahan dalam menemukan konsep nilai mutlak, Kesalahan konsep dalam penggunaan tanda pertidaksamaan, Kesalahan dalam langkah - langkah penyelesaian dan Kesalahan tidak melanjutkan proses penyelesaian. Subjek B melakukan 3 kesalahan yaitu : Kesalahan dalam menemukan konsep nilai mutlak, Kesalahan dalam langkah - langkah penyelesaian dan Kesalahan tidak melanjutkan proses penyelesaian. Sedangkan subjek $\mathrm{C}$ tidak melakukan satupun kesalahan.

Setelah mengetahui kesalahan subjek dalam menyelesaikan soal Bilangan Real dalam materi Nilai Mutlak pada mata kuliah Analisi Real dapat disimpulkan mahasiswa dikatakan membuat kesalahan apabila ia mengerjakan soal dengan tidak benar. Hal ini bisa terjadi pada proses penyelesaian soal maupun pada hasil akhir. Sehubungan dengan hal tesebut, penyebab kesalahan mahasiswa dalam 
menyelesaikan soal matematika dapat digolongkan menjadi tiga yaitu: mahasiswa itu sendiri, dosen dan fasilitas (buku acuan) yang digunakan.

\section{DAFTAR PUSTAKA}

1. Abdurrahman, M. 2006. .Pendidikan Bagi Anak Berkesulitan Belajar. Jakarta: Penerbit Rineka Cipta.

2. Badan Standar Nasional Pendidikan. 2006.Standar Isi Untuk Satuan Pendidikan Dasar dan Menengah. Jakarta

3. Lestari, I., 2018. Pengembangan Bahan Ajar Matematika dengan Memanfaatkan Geogebra Untuk Meningkatkan Kemampuan Pemahaman Konsep. Gaus:
Jurnal Pendidikan Matematika Vol. 01 No, 01 Mei 2018. P2620-95X, e-2620-8067

4. Pratiwi, D.D. 2016. Pembelajaran Learning Cycle $5 e$ Berbantuan Geogebra terhadap Kemampuan Pemahaman Konsep Matematis. Al-Jabar: Jurnal Pendidikan Matematika, Vol. 7, No. 2, Hal 191 - 202.

5. Khotimah. 2018. Meningkatkan Kemampuan Literasi Matematis dengan Pendekatan Metacognitive Guidance Berbatuan Geogebra. Gaus: Jurnal Pendidikan Matematika Vol. 01 No, 01 Mei 2018. P2620-95X, e-2620-8067 